BARBARA JANKOWIAK

ORCID 0000-0002-7660-2070

Agata Matysiak-BŁAsZcZYK

ORCID 0000-0002-7420-7288

Uniwersytet im. Adama Mickiewicza

$w$ Poznaniu

\title{
RYZYKO I OCHRONA W ŚRODOWISKU RÓWIEŚNICZYM. CZYLI O ZNACZENIU RELACJI KOLEŻEŃSKICH W ŻYCIU NASTOLATKÓW
}

AвSTRACT. Jankowiak Barbara, Matysiak-Błaszczyk Agata, Ryzyko i ochrona w środowisku rówieśniczym. Czyli o znaczeniu relacji koleżeńskich w życiu nastolatków [Risk and Protection in a Peer Environment. On the Importance of Friendly Relations in the Life of Teenagers]. Studia Edukacyjne nr 53, 2019, Poznań 2019, pp. 59-73. Adam Mickiewicz University Press. ISSN 1233-6688. DOI: 10.14746/se.2019.53.4

This article is devoted to the issue of peer relations, which are an important developmental factor and affect the welfare of adolescent boys and girls. According to many authors, relationships with peers during adolescence carry not only risk as a consequence of peer pressure to undertake unfavourable behaviors, but may also potentially contribute to well-being and life success. The analysis of available research results helped to distinguish two main risk factors resulting from peer relations, which include: mutual influence and modelling of disadaptive behaviours and rejection by peers. The protective factors, in turn, included: mutual influence and modelling of adaptive behaviours, a sense of happiness resulting from peer relations and compensating for other difficulties through peer relations.

Key words: peer relations, risk, protection, youth

Relacje rówieśnicze są niezwykle ważne dla rozwoju oraz dobrostanu adolescentek i adolescentów. Podczas okresu dojrzewania przekształceniu ulegają relacje społeczne nastolatków w kierunku wzrastającego znaczenia grupy rówieśniczej i osłabieniu zależnościowych relacji z rodzicami. Powstają nowe formy relacji międzyludzkich, na przykład rówieśnicze związki romantyczne. Ze względu na to, że jednym z kluczowych zadań jest uzyskanie niezależności i budowanie własnej autonomii, nastolatki wiele czasu poświęcają 
na kontakty z kolegami i koleżankami, poszukując akceptacji oraz budując własną pozycję w grupie.

Według Cristiny L. Reitz-Krueger, Alison G. Nagel, Lucy A. Guarnera i N. Dickona Reppucci, relacje z rówieśnikami w okresie dojrzewania niosą ze sobą nie tylko opisywane powszechnie w literaturze ryzyko jako następstwa presji rówieśników do podejmowania niekorzystnych zachowań, na przykład picia alkoholu, czy stosowania innych środków psychoaktywnych, a także przemocy i przestępczości, lecz także związki rówieśnicze mogą stanowić potencjał przyczyniający się do dobrego samopoczucia i sukcesów życiowych. Autorzy uznają więc, że rówieśnicy mogą stanowić zarówno źródło ryzyka, jak i ochrony dla nastolatków ${ }^{1}$. Także z badań Lösela i Farringtona wynika, że relacje rówieśnicze mogą być chroniące lub stwarzające ryzyko, w zależności czy rówieśnicy podejmują zachowania dewiacyjne czy nie. Rówieśnicy angażujący się w grupy i działania, które poprawiają zdrowie i dobre samopoczucie, takie jak grupy i organizacje szkolne lub religijne, stanowią czynnik chroniący, natomiast relacje $\mathrm{z}$ rówieśnikami, którzy mało angażują się w działania zwiększające zdrowie i poczucie dobrostanu mogą stanowić zagrożenie ${ }^{2}$.

Spędzanie czasu z rówieśnikami powoduje, że zachowania które podejmują członkowie grupy stają się modelami zachowań dla pozostałych nastolatków, a normy charakterystyczne dla grupy rówieśniczej łatwo podlegają internalizacji. Warto podkreślić, że młody człowiek spędza z rówieśnikami ponad połowę swojego wolnego czasu ${ }^{3}$, dlatego też sposób funkcjonowania grupy rówieśniczej ma wpływ na styl życia młodych ludzi do niej należących. Rówieśnicy odgrywają bardzo ważną rolę w procesie socjalizacji, a przejście przez ten etap doświadczeń życiowych uważany jest za niezbędny czynnik kształtowania osobowości ${ }^{4}$. Wyniki prowadzonych współcześnie badań przyczyniły się do podkreślenia statusu rówieśniczego i akceptacji lub odrzucenia wśród rówieśników jako silnie powiązanego z późniejszą psychopatologią lub zdrowiem. Interakcje z rówieśnikami obejmują szeroki zakres zachowań (np. prospołecznych, agresywnych, wycofania, wiktymizacji), relacji (np. przyjaźnie diadyczne, kliki, sieci), status i reputacje (np. akceptacja/ odrzucenie rówieśników, popularność) oraz procesy rozwojowe (np. wsparcie rówieśników, wpływ/socjalizacja). Co więcej, doświadczenia te występu-

\footnotetext{
${ }^{1}$ C.L. Reitz-Krueger i in., Community Influence on Adolescent Development, [w:] Handbook of Adolescent Behavioral Problems: Evidence-Based. Approaches to Prevention and Treatment, red. T.P. Gullotta i in., New York 2015, s. 71-84.

2 Za: J.L Romano, Prevention Psychology: Enhancing Personal and Social Well-Being, American Psychological Association, 2015, s. 49-50.

${ }^{3}$ M. Bardziejewska, Okres dorastania. Jak rozpoznać potencjał nastolatków? [w:] Psychologiczne portrety człowieka. Praktyczna psychologia rozwojowa, red. A.I. Brzezińska, Gdańsk 2015.

${ }^{4}$ Zob. A. Cybal-Michalska i in., Młodzież w sferze doświadczeń edukacyjno-zawodowych, Poznań 2018.
} 
ją w różnych formach (np. osobiście, online) i różnią się funkcją w rozwoju ${ }^{5}$. Ponieważ - podkreślmy raz jeszcze - związki z osobami w tym samym wieku mogą stanowić zarówno pozytywny potencjał rozwojowy, jak i przejawiać ryzyko dla prawidłowego rozwoju, $\mathrm{w}$ analizie dostępnych badań najpierw przedstawimy rozwój relacji rówieśniczych w okresie dorastania, a następnie będziemy eksplorować obydwa aspekty - więc ochronę i ryzyko.

\section{Rozwój relacji rówieśniczych w okresie adolescencji}

Newmanowie w odniesieniu do okresu wczesnej adolescencji przyjęli jako podstawowy kryzys - identyfikacja z grupą versus alienacja, natomiast dla etapu późnej adolescencji - tożsamość versus dyfuzja tożsamości. W związku z tym dla młodszych adolescentów bardziej charakterystyczne jest poszukiwanie odpowiedzi na pytanie o ich relacje z grupą rówieśników zanim odnajdą odpowiedź na pytanie na temat ich relacji z rodziną i stworzą własną tożsamość. Oznacza to, że młodzież najpierw rozwija poczucie tożsamości grupowej jako wstęp do rozwoju poczucia tożsamości indywidualnej ${ }^{6}$. Dlatego, adolescencja charakteryzuje się zwiększoną wrażliwością na aprobatę rówieśniczą, a wpływ rówieśników dotyczy zarówno sposobu spędzania wolnego czasu, wyglądu zewnętrznego, jak i ogólnie - stylu życia. Członków grupy łączy więź grupowa wynikająca ze wspólnoty zainteresowań i potrzeb, razem wykonywanych czynności i realizowanych zadań. Dzięki wytworzeniu się więzi grupa staje się zwarta, spoista, zdolna do skutecznego działania. Na podłożu takich związków kształtuje się poczucie solidarności, aprobata jej celów działania oraz uznanie ich za własne, dlatego młodzi ludzie bardzo silnie identyfikują się z grupą ${ }^{7}$.

Grupa rówieśnicza spełnia istotną funkcję, polegającą na rozluźnieniu więzów łączących dziecko z rodziną i przedstawia dziecku dodatkowe, niekiedy alternatywne, modele zachowań, a także norm i wartości. W rezultacie dziecko uczy się, jak radzić sobie z poglądami tych, których uważa za ważnych, tych, których socjologowie określają mianem „znaczących innych"8. Uczestnictwo $\mathrm{w}$ grupie rówieśniczej zaspokaja liczne potrzeby psychiczne i społeczne jednostki.

${ }^{5}$ S. Choukas-Bradley, M.J. Prinstein, Peer Relationships and the Development of Psychopathology, [w:] Handbook of Developmental Psychopathology, red. M. Lewis, K.D. Rudolph, New York 2014, s. 185.

${ }^{6}$ B.M. Newman, P.R. Newman, Development through life: a psychosocial approach, California 1987, s. 320.

7 Z. Skorny, Proces socjalizacji dzieci i młodzieży, Warszawa 1987, s. 71.

${ }^{8}$ N. Goodman, Wstęp do socjologii, Poznań 1997, s. 93. 
(...) poprzez uczestnictwo w grupie rówieśniczej młody człowiek może stosunkowo najłatwiej odnaleźć przynależność, afiliację i akceptację oraz realizować status osoby niezależnej, czego nie może osiągnąć ani w ramach swej rodziny, ani w ramach społeczeństwa, które nie oferuje mu jeszcze pełnego uczestnictwa9

Funkcjonowanie $\mathrm{w}$ relacjach rówieśniczych przyczynia się więc do budowania autonomii, która jest kluczowym osiągnięciem rozwojowym okresu dorastania.

Dunphy analizował funkcjonowanie młodzieżowych grupy rówieśniczych. Zidentyfikował dwie struktury charakterystyczne dla okresu młodzieńczego: małe grupy bliskich przyjaciół tej samej płci, którą nazwał klikami (cliques), i duże sieci mieszane, które nazwał tłumami (crowds). Te struktury rówieśnicze różnią się nie tylko wielkością, ale funkcją rozwojową. Kliki jednopłciowe chłopców i dziewcząt najpierw łączą się w formę klik mieszanych. Następnie łączą się, aby utworzyć mieszane tłumy i te tłumy zastępują kliki jako miejsce rozwoju psychospołecznego nastolatków. Dunphy twierdził, że podstawową funkcją klik jest wspieranie tworzenia tłumów, podczas gdy tłum ma funkcję tworzenia kontekstu rozwoju heteroseksualnego nastolatków poprzez dostarczanie dostępu do potencjalnych romantycznych partnerów i tworzenia kontekstu, w którym można rozpocząć randkowanie ${ }^{10}$. Z badań wynika, że nastolatkowie posiadający wielu przyjaciół przeciwnej płci mają większe szanse na posiadanie romantycznego związku niż inni adolescenci ${ }^{11}$.

Młodzież zanim wejdzie w dorosłość, ma szanse doświadczyć pierwszej miłości oraz pierwszych doświadczeń seksualnych ${ }^{12}$ - od masturbacji, poprzez petting, do inicjacji seksualnej ${ }^{13}$. Efektem końcowym tego etapu ma być stworzenie przez młodego człowieka intymnego związku łączącego uczuciowość i seksualność ${ }^{14}$. Ze względu na wyraźną dezintegrację seksualną okresu dorastania, czyli rozdźwięk między uczuciowością, podnieceniem i pożądaniem $^{15}$, tworzenie relacji romantycznych jest ważnym wyzwaniem dla adole-

\footnotetext{
${ }^{9}$ Misztal B., Grupy rówieśnicze młodzieży, Warszawa 1974, s. 54.

${ }^{10}$ D. Dunphy, The social structure of urban adolescent peer groups, Sociometry, 1963, 26, s. 230246.

${ }^{11} \mathrm{~J}$. Connolly, A. Johnson, Adolescents' romantic relationships and the structure and quality of their close interpersonal ties, Personal Relationships, 1996, 3, 3, s. 185-195.

12 I. Obuchowska, Adolescencja, [w:] Psychologia rozwoju czlowieka. Charakterystyka okresów życia człowieka, t. 2, red. B. Harwas-Napierała, J. Trempała, Warszawa 2005, s. 163-202.

${ }_{13}$ Zob. M. Beisert, Dorastanie seksualne - pomost ku dorostości, [w:] Psychologia rozwiazywania problemów szkoły, red. J. Miluska, Poznań 2001; taże, Trud dorastania seksualnego, [w:] Seksualność w cyklu życia człowieka, red. M. Beisert, Poznań 2004.

${ }_{14}$ B. Jankowiak, A. Gulczyńska, Wczesna inicjacja seksualna młodzieży - przyczyny i konsekwencje, Kultura - Społeczeństwo - Edukacja, 2014, 5(1), s. 172.

${ }^{15}$ Zob. więcej: O.F. Kernberg, Zwiazki miłosne, Poznań 1998.
} 
scentek i adolescentów. Związki miłosne nastolatków nazywane są niekiedy związkami preintymnymi,

ze względu na niedojrzałość tożsamości, jej struktur i granic, co decyduje o jakości i trwałości tych związków. Ich główną funkcją jest kształtowanie się gotowości do wchodzenia w bliskie związki w okresie dorosłości oraz wspomaganie procesu formowania się tożsamości poprzez uzyskiwane w relacjach miłosnych informacje zwrotne na temat jakości tożsamości obojga partnerów ${ }^{16}$.

Ponadto, jak podkreślają Wyndol Furman i Laura Shaffer, związki intymne nastolatków odgrywają podstawową rolę w rozwoju w okresie adolescencji, w tym w: rozwoju tożsamości, transformacji relacji rodzinnych, rozwoju bliskich relacji z rówieśnikami, rozwoju seksualności oraz dla szkolnych osiągnięć i planowania kariery. A więc dla kluczowych zadań rozwojowych ${ }^{17}$. Carolyn Tucker Halpern uważa, że nawiązywanie romantycznych relacji i inicjowanie aktywności seksualnej to klucz do rozwoju w okresie dojrzewania, gdyż młodzi ludzie dzięki podejmowaniu nowych aktywności realizują zadania rozwojowe etapu dorastania ${ }^{18}$.

\section{Ryzyko w środowisku rówieśniczym}

Analiza dostępnych wyników badań pozwoliła na wyróżnienie dwóch głównych czynników ryzyka wynikających z relacji rówieśniczych. Należą do nich: wzajemne wywieranie wpływu i modelowanie dezadaptacyjnych zachowań oraz odrzucenie przez rówieśników.

Zdaniem Cristiny L. Reitz-Krueger, Alison G. Nagel, Lucy A. Guarnera i N. Dickona Reppucci, presja rówieśnicza jest kwintesencją tego, jak rozumiany jest negatywny wpływ rówieśniczy. Jednak większość badań nie uwzględnia otwartej presji na podejmowanie antyzdrowotnych lub problemowych zachowań, ale raczej ryzyko jest operacjonalizowane jako afiliacja z innymi młodymi modelującymi te zachowania i mogącymi (choć niekoniecznie) wyraźnie zachęcać do nich. Czynnikiem ryzyka jest więc wzajemne wywieranie wpływu i modelowanie ${ }^{19}$ dezadaptacyjnych zachowań.

${ }^{16}$ K. Piotrowski, J. Wojciechowska, B. Ziółkowska, Rozwój nastolatka. Późna faza dorastania, [w:] Niezbędnik dobrego nauczyciela, red. A.I. Brzezińska, Warszawa 2014, s. 26.

${ }_{17}$ W. Furman, L. Shaffer, The role of romantic relationships in adolescent development, [w:] Adolescent romantic relations and sexual behavior: Theory, research and practical implications, red. P. Florsheim, Mahwah, NJ 2003, s. 3.

${ }^{18}$ C. Tucker Halpern, Biological Influences on Adolescent Romantic and Sexual Behavior, [w:] Adolescent romantic relations and sexual behavior: Theory, research and practical implications, red. P. Florsheim, Mahwah, NJ 2003.

${ }^{19}$ C.L. Reitz-Krueger i in., Community Influence, s. 71-84. 
Negatywny (dobrze opisany w literaturze efekt) ma przynależność do dewiacyjnych grup rówieśniczych, który wiąże się z zaburzeniami zachowania i używaniem substancji psychoaktywnych ${ }^{20}$. Wzrost ekspozycji na negatywnych rówieśników w późnym okresie dojrzewania przewidywał większe prawdopodobieństwo zachowań problemowych ${ }^{21}$. Richard Jessor do grupy czynników ryzyka zaliczonych przez niego do systemu spostrzegania środowiska włącza modele zachowań problemowych wśród znajomych. Stanowią one zagrożenie, ponieważ dostarczają okazji do uczenia się, jak angażować się w zachowania problemowe, oferują dostęp do zaopatrzenia we wszystko co może być potrzebne do realizacji zachowań problemowych, jak na przykład papierosy, alkohol, narkotyki. Kolejnym czynnikiem jest także orientacja na znajomych (a nie rodziców). Stanowi ona ryzyko, ponieważ to głównie rodzice, a nie rówieśnicy reprezentują kontrolę przeciwko dewiacyjnym i łamiącym normy społeczne zachowaniom oraz dostarczają modeli dla konwencjonalnych wartości, postaw i aktywności ${ }^{22}$. Według Pawełczyńskiej, brak kontroli nad grupami dzieci i młodzieży ze strony rodziców oraz innych instytucji wychowawczych stwarza szerokie zagrożenie stopniowego wykolejenia członków takich grup, podobnie jak przejmowanie przez grupę dzieci lub młodzieży podkultury przestępczej środowiska, z którego pochodzą lub z którym stykają się z racji sąsiedztwa i wzmacniającą (dla wykolejenia) rolą grupy rówieśniczej wśród młodzieży, której inne grupy społeczne nie zapewniają dostatecznej afiliacji ${ }^{23}$.

Zdaniem Daniela J. Flannery, Davida Husseya i Erica Jefferisa, negatywne wpływy rówieśnicze przyczyniają się do używania środków psychoaktywnych ${ }^{24}$. Prawdopodobieństwo zachowań ryzykownych rośnie najbardziej, jeśli młodzi ludzie spędzają czas w towarzystwie rówieśników pijących alkohol lub używających narkotyków ${ }^{25}$.

W odniesieniu do ryzykownych zachowań seksualnych - jak wynika z badań - modelowanie zachowań przez znajomych również ma istotne zna-

${ }^{20}$ S.S. Luthar, Resilience in development: A synthesis of research across five decades, [w:] Developmental Psychopathology: Risk, disorder, and adaptation, red. D. Cicchetti, D.J. Cohen, New York 2006, s. 770 .

${ }^{21}$ Fleming i in., Relationships between level and change in family, school, and peer factors during two periods of adolescence and problem behavior at age 19, Journal of Youth and Adolescence, 2010, 39(6), s. 670-682.

${ }^{22}$ R. Jessor i in., Protective factors in adolescent problem behavior: Moderator effects and developmental change, Developmental Psychology, 1995, 31, s. 923-933.

23 A. Pawełczyńska, Przestępczość grup nieletnich, Warszawa 1964, s. 219.

${ }^{24}$ D.L. Flannery, D. Hussey, E. Jefferis, Adolescent Delinquency and Violent Behavior, [w:] Handbook of adolescent behavioral problems: evidence-based approaches to prevention and treatment, red. T.P. Gullotta, G.R. Adams, New York 2005, s. 421.

${ }_{25}$ Zob. K. Bobrowski, Czas wolny a zachowania ryzykowne młodzieży, Alkoholizm i Narkomania, 2007, 20, 3, s. 267-287 
czenie. Wczesnej inicjacji seksualnej sprzyja spędzanie większości wieczorów $\mathrm{w}$ towarzystwie rówieśników ${ }^{26}$ oraz posiadanie znajomych, którzy są aktywni seksualnie ${ }^{27}$. Wysokie znaczenie, jakie młodzież przypisuje grupie rówieśniczej (co sprzyja podejmowaniu konformistycznych zachowań) także wiąże się z podejmowaniem ryzykownych zachowań seksualnych ${ }^{28}$.

Młodzież może być związana z rówieśnikami na różne sposoby. Na przykład, szkoły często umieszczają w jednej klasie dzieci na podstawie poziomu osiągnięć. Klasy zawierające uczniów o najniższych sukcesach szkolnych mogą ułatwiać relacje między młodzieżą, która ma mniejsze szanse na internalizację szkolnych norm i oczekiwań ${ }^{29}$.

Wśród nastoletnich dziewcząt przynależność do grupy chłopców niesie ze sobą szczególne ryzyko. Dziewczyny popełniające czyny przestępcze zgłaszają więcej przyjaźni płci przeciwnej, niż dziewczyny nie zaangażowane $\mathrm{w}$ łamanie prawa. $Z$ informacji o kontekście popełnianych przestępstw, dziewczyny najczęściej zgłaszają, że były z grupą mężczyzn i kobiet ${ }^{30}$. Można więc przypuszczać, że dziewczyny z gimnazjów koedukacyjnych są bardziej narażone na przestępczość niż dziewczyny w szkołach kobiecych ${ }^{31}$.

Innym niezwykle istotnym czynnikiem ryzyka jest odrzucenie przez rówieśników. Odrzucona młodzież rzadziej ma możliwości wejścia w bliskie relacje z prospołecznymi rówieśnikami, a więc ma mniej okazji do modelowania pozytywnych zachowań społecznych. Ponadto, udowodniono na wszystkich etapach rozwoju związek między odrzuceniem przez rówieśników a doświadczaniem w późniejszym czasie objawów eksternalizacyjnych ${ }^{32}$ oraz internalizacyjnych ${ }^{33}$. Cillessen, Van Ijzendoorn, Van Lieshout i Hartup ujawnili, że młodzież odrzuconą przez rówieśników można sklasyfikować w podgrupach odrzucona-agresywna, odrzucona-wycofana i inna odrzucona młodzież $\dot{z}^{34}$. Późniejsze badania wykazały, że odrzucona agresywna mło-

${ }^{26}$ Z. Izdebski, Wiedza, przekonania o HIV/AIDS w społeczeństwie polskim. Zachowania seksualne, Warszawa 2000.

${ }^{27}$ R.E. Sieving i in., Friends' influence on adolescents' first sexual intercourse, Perspectives on Sexual and Reproductive Health, 200, 38, s. 13-19.

${ }^{28}$ L. Rew, T. Carver, Ch. Li, Early and risky sexual behavior in a sample of rural adolescents, Issues in Comprehensive Pediatric Nursing, 2011, 34, s. 189-204.

${ }^{29}$ Dishion, Patterson, Stoolmiller i Skinner, 1991, za: C.L. Reitz-Krueger i in., Community Influence, s. 72.

${ }^{30}$ Giordino, 1978, za: S.L. Foster, Aggression and Antisocial Behavior in Girls, [w:] Handbook of Behavioral and Emotional Problems in Girls, red. D.J. Bell, S.L. Foster, E.J. Mash, New York 2005, s. 149-181.

${ }^{31}$ S.L. Foster, Aggression and Antisocial Behavior.

${ }^{32}$ S. Choukas-Bradley, M.J. Prinstein, Peer Relationships, s. 187.

33 Tamże, s. 188.

34 A.H. Cillessen i in., Heterogeneity among peer-rejected boys: Subtypes and stabilities, Child Development, 1992, 63(4), s. 893-905. 
dzież ma znacznie większe ryzyko zwiększenia trajektorii zachowań eksternalizacyjnych w porównaniu z młodzieżą, która jest tylko agresywna, tylko odrzucona lub ani agresywna, ani odrzucona ${ }^{35}$. Odrzucenie może skutkować negatywnymi konsekwencjami w wielu obszarach, gdyż zwiększa także prawdopodobieństwo zaburzeń internalizacyjnych, porzucenia szkoły, przestępczości ${ }^{36}$.

Potencjalny mechanizm wyjaśnia model przetwarzania informacji społecznej Cricka i Dodge, zgodnie z którym stymulacja społeczna wymaga kodowania i interpretacji przez jednostki (tj. atrybucji przyczyn i zamiarów), a następnie wyboru celów społecznych, generowania behawioralnych opcji odpowiedzi, wyboru konkretnej strategii behawioralnej, a na koniec podjęcia tego zachowania ${ }^{37}$. Młodzież odrzucona przez rówieśników może popełniać specyficzny typ błędu, który powoduje w przyszłości ryzyko nie przystosowawczych interakcji z rówieśnikami i objawy psychopatologiczne. Odrzucona młodzież zamiast doświadczania sytuacji społecznych, które ułatwiają rozwój odpowiednich umiejętności społecznych i kompetencji, nabywa doświadczeń społecznych, które uczą ich tego, że rówieśnicy są wrogo nastawieni, co powoduje, że w dalszym życiu młodzi ludzie mają tendencję do interpretowania łagodności innych lub wysyłanych niejednoznacznych wskazówek społecznych jako wrogich intencji ${ }^{38}$. To wrogie nastawienie może być związane z nadmierną czujnością wobec wrogich sygnałów. Młodzi odrzuceni przez rówieśników, zwłaszcza odrzuceni agresywnie, wykazują tendencję do wrogich atrybucji ${ }^{39}$.

Oprócz roli procesów społeczno-poznawczych, związek między odrzuceniem rówieśniczym a objawami eksternalizacyjnymi może być wyjaśniony przez skłonność odrzuconej młodzieży do nawiązywania przyjaźni z innymi, którzy także mają trudności, tworząc dewiacyjne grupy rówieśnicze ${ }^{40}$. Młodzież z rodzin, w których panuje zła atmosfera wychowawcza, bądź mająca poważne konflikty w szkole (choćby z racji złych wyników w nauce), dąży najczęściej do tym bardziej silniejszego zaznaczania swej przynależności do

35 K. Bierman, J.B. Wargo, Predicting the longitudinal course associated with aggressive rejected, aggressive (non rejected), and rejected (non aggressive) status, Development and Psychopathology, 1995, 7(4), s. 669-682; M.J. Prinstein, A.M. La Greca, Childhood peer rejection and aggression as predictors of adolescent girls' externalizing and health risk behaviors: A 6-year longitudinal study, Journal of Consulting and Clinical Psychology, 2004, 72(1), s. 103-112.

36 S.S. Luthar, Resilience in development, s. 770.

37 N.R. Crick, K.A. Dodge, A review and reformulation of social information processing mechanisms in children's social adjustment, Psychological Bulletin, 1994, 115, s. 74-101.

38 S. Choukas-Bradley, M.J. Prinstein, Peer Relationships, s. 188.

39 K.A. Dodge, J.D. Coie, Social-information processing factors in reactive and proactive aggression in children's peer groups, Journal of Personality and Social Psychology, 1987, 53(6), s. 11461158.

40 S. Choukas-Bradley, M.J. Prinstein, Peer Relationships, s. 189. 
grupy rówieśniczej i wyzwolenia w niej swej naturalnej potrzeby działania. W wypadku młodzieży odrzuconej na margines innych środowisk będzie to często grupa o negatywnym nastawieniu wobec wartości uznawanych przez instytucje wychowawcze i lekceważąca autorytet zarówno osób dorosłych, jak i rówieśników stawianych gdzie indziej za wzór ${ }^{41}$. Prowadzić to może do świadomej działalności antyspołecznej, dającej poczucie siły i niezależności oraz swoistego prestiżu zarówno w grupie, jak i w szerszych kręgach ${ }^{42}$. Wiązania się nieletnich i młodocianych w grupy, które często przekształcają się $\mathrm{z}$ niekontrolowanych grup $\mathrm{w}$ grupy kradnące i chuligańskie, odgrywa w etiologii wykolejenia społecznego bardzo ważną rolę. Dla dzieci i młodzieży przeżywających trudności w rodzinie i szkole tego rodzaju grupa rówieśnicza jest bowiem środowiskiem atrakcyjnym ze względu na to, że zaspokaja, choć w sposób wypaczony, takie naturalne potrzeby, jak: potrzeba przynależności, aprobaty, bezpieczeństwa, przygody i emocji, że daje możność pełnienia uznanej przez jakąś społeczność roli, czy też kompensuje rzeczywiste bądź urojone krzywdy doznane w szkole i domu rodzinnym ${ }^{43}$. Badania Hirschiego potwierdziły powszechnie podzielany pogląd, według którego realizacja zamierzeń przestępczych następuje zwykle $w$ małych grupach i parach, z czego badacze wyprowadzają wniosek o kompensującym charakterze grupowego zachowania przestępczego - kompensacji braku pozytywnego kontaktu i uczuć rodzinnych. Fakty te budzą kolejne pytanie związane z pierwotnością i przyczynowym związkiem między więzią w grupie przestępczej i zachowaniami przestępczymi. Chociaż nie ma tu jednoznacznych rozstrzygnięć, to przyjmuje się, że wiele przestępczych zachowań jest wyrazem wspólnych dążeń, że przyjaźń i postawy rozwijają się równocześnie jako wspólnie podzielone przekonania ${ }^{44}$.

W literaturze przedmiotu odnajdujemy badania dwóch przyczyn odrzucenia - po pierwsze ze względu na stosowanie przemocy samej odrzuconej młodzieży lub bycie jej ofiarą. Na przykład, zdaniem Sharon L. Foster, stosowanie przez adolescentów i adolescentki jawnej agresji koreluje dodatnio z odrzuceniem przez rówieśników we wczesnym i średnim dzieciństwie ${ }^{45}$. Daniel J. Flannery, David Hussey i Eric Jefferis dokonali analizy czynników ochronnych oraz ryzyka powstawania zachowań przestępczych i przemocy wśród młodzieży. Negatywne wpływy rówieśnicze przyczyniają się, zdaniem tych autorów, do podejmowania zachowań agresywnych i przestęp-

${ }^{41}$ L. Mościcka, Przestęczoośc nieletnich, Wrocław 1970, s.195-196.

${ }^{42}$ A. Kossowska, A. Mościkier, Grupa rówieśników a przestępczość młodzieży, [w:] Zagadnienia nieprzystosowania społecznego i przestępczości w Polsce, Wrocław - Warszawa - Kraków - Gdańsk 1978, s. 372.

43 A. Krukowski, Problemy zapobiegania przestępczości, Warszawa 1982, s. 27.

${ }^{44}$ Tamże, s.27

45 S.L. Foster, Aggression and Antisocial Behavior, s. 149-181. 
czych. Jeśli dzieci przejawiają tendencje antyspołeczne w młodym wieku, to jest bardziej prawdopodobne, że zostaną odrzucone przez rówieśników, ze względu na ich agresywne zachowania i stosowanie przymusu wobec innych. Zachowania antyspołeczne i odrzucenie przez rówieśników służy następnie jako czynniki ryzyka dla nawiązywania dewiacyjnych relacji rówieśniczych. Grupy rówieśnicze są miejscem dla konsolidacji negatywnych i agresywnych zachowań dla młodzieży, która już zmierza w tym kierun$\mathrm{ku}$. Relacje $\mathrm{z}$ antyspołecznymi rówieśnikami mogą ponadto przyczynić się do eskalacji aspołecznych zachowań, w tym uzależnień i przestępczości oraz porażek szkolnych ${ }^{46}$. Zdaniem Foster, która analizowała problem agresji dziewcząt, związek między jawną agresją i odrzuceniem niekoniecznie oznacza, że jawnie agresywne dziewczyny są pozbawione przyjaciół. Agresywne dziewczyny mogą należeć do sieci społecznych, a te sieci przypuszczalnie zawierają podobnie agresywne dziewczyny ${ }^{47}$. Agresja sprzyja odrzuceniu, co z kolei zmniejsza przynależność do prospołecznych grup rówieśników i zwiększenia interakcji z rówieśnikami o podobnie słabych umiejętnościach społecznych. Prawdopodobnie w dewiacyjnej grupie rówieśniczej agresywne dziecko kontynuuje odreagowania napięć poprzez agresję i może nawet podejmować zachowania przestępcze. Rola dewiacyjnych rówieśników może być jeszcze silniejsza u dziewczyn, które manifestowały eksternalizacyjne problemy przed dojrzewaniem płciowym ${ }^{48}$.

Z drugiej strony, do odrzucenia przez rówieśników przyczynia się także doświadczenie wiktymizacji. Agresja rówieśnicza może przybierać różne formy, takie jak fizyczne znęcanie się, agresja relacyjna lub przemoc partnerska. Będąc ofiarą któregokolwiek z nich, stanowi dla nastolatków ryzyko różnych problemów emocjonalnych i behawioralnych ${ }^{49}$. Na przykład, nastolatki doświadczające przemocy na randkach są bardziej narażone na depresję, zaburzenia jedzenia, myśli samobójcze i zażywanie narkotyków, a także na negatywne osiągniecia akademickie, takie jak słabe oceny lub brak ukończenia szkoły $^{50}$.

Zdaniem Sylwii Jaskulskiej i Wiesława Poleszaka, wykluczenie rówieśnicze to proces przebiegający od maksymalnego włączenia do maksymalnego wykluczenia. Dlatego, należy analizować relacje rówieśnicze przez pryzmat

${ }^{46}$ D.J. Flannery, D. Hussey, E. Jefferis, Adolescent Delinquency and Violent Behavior, [w:] Handbook of adolescent behavioral problems : evidence-based approaches to prevention and treatment. red. T. P. Gullotta, G. R. Adams, New York 2005: Springer.

47 Cairns, Cairns, Neckerman, Gest, Gariepy, 1988, za: S.L. Foster, Aggression and Antisocial Behavior, s. 149-181.

48 S.L. Foster, Aggression and Antisocial Behavior, s. 149-181.

${ }^{49}$ C.L. Reitz-Krueger i in., Community Influence, s. 71-84.

50 Ackard, Eisenberg, Neumark-Sztainer, 2007; Banyard, Cross, 2008; Ackard, Neumark-Sztainer, 2002, za: C.L. Reitz-Krueger i in., Community Influence, s. 73. 
tego, jak przebiega ich nawiązywanie i gdzie pojawiają się problemy. Im wcześniej zainterweniujemy w zaburzony proces włączania, tym interwencja ta będzie mniej kosztowna i bardziej efektywna ${ }^{51}$.

\section{Ochrona w środowisku rówieśniczym}

Chociaż skojarzenia dotyczące relacji rówieśniczych są często zdominowane przez obrazy czyhającego na młodych ryzyka, to jak wynika z badań, relacje koleżeńskie nastolatków również mają potencjał do buforowania ryzyka i przynoszenia wyjątkowych korzyści dla ich zdrowia i dobrego samopoczucia ${ }^{52}$. Analiza dostępnych wyników badań pozwoliła na wyróżnienie trzech rówieśniczych czynników chroniących rozwój. Należą do nich: wzajemne wywieranie wpływu i modelowanie adaptacyjnych zachowań, relacje rówieśnicze jako źródło szczęścia, kompensowanie innych trudności poprzez relacje z rówieśnikami.

Wzajemne wywieranie wpływu i modelowanie zachowań może być nie tylko sposobem uczenia się antyzdrowotnych zachowań, ale także rówieśniczym czynnikiem chroniącym rozwój młodzieży. Suniya S. Luthar odnośnie relacji rówieśniczych podkreśla znaczenie pozytywnych relacji rówieśniczych, które mogą pełnić ważną funkcję pomocową, szczególnie dla dzieci z grup ryzyka ${ }^{53}$. Zdaniem Jessora, funkcję ochronną pełnią modele konwencjonalnych zachowań wśród znajomych, a więc relacje z rówieśnikami, którzy są członkami szkolnych klubów, angażują się religijnie, mają dobre oceny $\mathrm{w}$ szkole. Funkcja ochronna wynika z zaangażowania w relacje z osobami podejmującymi konwencjonalne (a nie problemowe) zachowania oraz spędzania czasu na konwencjonalnych aktywnościach ${ }^{54}$. Wyniki badań potwierdzają także, że kontakty z rówieśnikami, którzy potępiają przemoc hamują powstawanie zachowań agresywnych u swoich kolegów ${ }^{55}$. Istnieją również badania wskazujące na to, że rówieśnicy wpływają na skuteczność terapii. Młodzi ludzie, którzy mają znajomych wspierających w abstynencji lepiej reagowali na leczenie ${ }^{56}$.

\footnotetext{
${ }^{51}$ S. Jaskulska, W. Poleszak, Wykluczenie rówieśnicze, [w:] Wychowawcze i społeczno-kulturowe kompetencje wspótczesnych nauczycieli. Wybrane konteksty, red. J. Pyżalski, Łódź 2015.

${ }^{52}$ C.L. Reitz-Krueger i in., Community Influence, s. 73.

${ }^{53}$ S.S. Luthar, Resilience in development, s. 770.

${ }^{54}$ R. Jessor, Risk Behavior in Adolescence: A Psychosocial Framework for Understanding and Action, Journal of Adolescent Health, 1991, 12, s. 602-603.

${ }^{55}$ D.L. Flannery, D. Hussey, E. Jefferis, Adolescent Delinquency, s. 422.

${ }^{56}$ K.C. Winters i in., Adolescent Substance Abuse Treatment: A Review of Evidence-Based Research, [w:] Adolescent Substance Abuse Evidence-Based Approaches to Prevention and Treatment, red. C.G. Leukefeld, T.P. Gullotta, M. Staton-Tindall, New York 2009, s. 86.
} 
Wraz z rosnącą otyłością u dzieci i młodzieży rola rówieśników w zdrowym żywieniu i fizycznej działalności staje się coraz bardziej powszechnym celem badania ${ }^{57}$. Młodzież, która ma więcej znajomych, w porównaniu z młodzieżą samotną lub odrzuconą, zwykle angażuje się częściej i w bardziej zróżnicowane rodzaje aktywności fizycznej. Rówieśnicy są również w stanie modelować zdrowe zachowania żywieniowe ${ }^{58}$.

Rówieśnicy zachęcają do pozytywnych zachowań w bardziej bezpośredni sposób poprzez presję rówieśników. McLeod ze współpracownikami przeprowadził (2008) wywiady z parami bliźniąt, gdzie jeden palił, a drugi nie. Niepalący raportowali o silnej presji ze strony swoich przyjaciół by nie palić i czuli, że palenie nie było zgodne z obrazem ich grupy rówieśniczej ${ }^{59}$. Wsparcie rówieśnicze i zachowania prospołeczne zostały również połączone z konsekwentnym używaniem prezerwatyw wśród aktywnych seksualnie nastoletnich Afroamerykanów ${ }^{60}$.

Relacje rówieśnicze mogą stanowić dla nastolatków źródło szczęścia. W jednym z badań uzyskano wyniki wskazujące, że codzienne pozytywne doświadczenia z rówieśnikami były predyktorem optymizmu wśród młodzieży ${ }^{61}$. Ustalono, że stosunki między rówieśnikami u nastolatków mają pozytywny wpływ na ich wyniki w nauce i ogólną samoocenę ${ }^{62}$. Prowadzone badania wykazały także, że przywiązanie do rówieśników jest predyktorem poczucia własnej wartości ${ }^{63}$ oraz wykazano interakcje wsparcia rówieśniczego dla pozytywnego nastroju ${ }^{64}$.

Wreszcie relacje rówieśnicze mogą pomóc w buforowaniu narażenia na inne czynniki ryzyka w domu lub środowisku lokalnym. Na przykład, przyjaźń jest niezwykle ważna, kiedy w rodzinie pochodzenia dochodzi do negatywnych zjawisk, na przykład przemocy. Istnieją dowody, że odporność (resilience) jest rzadka wśród dzieci doświadczających przemocy w rodzinie.

57 S. Salvy i in., Influence of peers and friends on children's and adolescents' eating and activity behaviors, Physiology and Behavior, 2012, 106(3), s. 369-378.

58 Tamże.

59 Za: C.L. Reitz-Krueger i in., Community Influence, s. 74.

${ }^{60}$ Elkington, Bauermeister, Zimmerman, 2011, za: Tamże,

${ }^{61}$ S. Orejudo i in., Optimism in adolescence: A crosssectional study of the influence of family and peer group variables on junior high school students, Personality and Individual Differences, 2012, 52, s. 812-817.

${ }^{62}$ G.A. Liem, A.J. Martin, Peer relationships and adolescents' academic and non-academic outcomes: same-sex and opposite-sex peer effects and the mediating role of school engagement, The British Psychological Society, 2011, s. 183-206.

${ }^{63} \mathrm{H}$. Liberska, K. Głogowska, M. Deja, Przywiazanie do rodziców i rówieśników jako predyktor samooceny w okresie adolescencji, Czasopismo Psychologiczne, 2016, 22, 2, s. 219-227.

${ }^{64}$ S.M. Weinstein i in., The Time-Varying Influences of Peer and Family Support on Adolescent Daily Positive and Negative Affect, Journal of Clinical Child and Adolescent Psychology, 2006, 35, 3, s. 420-430. 
W tym kontekście prowadzono badania, wskazujące na znaczenie pozytywnych relacji z alternatywnymi osobami udzielającymi opieki i wsparcia jako przyczyniającymi się do zwiększenia szans na pozytywny rozwój. Na przykład, posiadanie odwzajemnionej relacji przyjacielskiej wiązało się ze wzrostem poczucia własnej wartości, co przyczyniało się do zmniejszenia poczucia samotności, zwiększenia postrzeganej akceptacji, poprawy umiejętności społecznych, a także modyfikował się uaktualniany wzór przywiązania ${ }^{65}$. Dla młodzieży z rodzin o słabej koherencji i ubogich zdolnościach adaptacyjnych przyjaźnie wysokiej jakości były pozytywnie powiązane z kompetencjami społecznymi i poczuciem własnej wartości ${ }^{66}$.

Podczas gdy rówieśnicy z pewnością mają potencjał do działania jako czynnik ryzyka w życiu nastolatków, to jednak relacje ze zdrowymi, prospołecznymi rówieśnikami mogą promować pozytywne zachowania i odpornośćc7. Analiza dostępnych badań wskazuje więc, że poczucie dobrostanu, zdrowia i podejmowane zachowania są często wynikiem kontaktów z kolegami i koleżankami. Wspieranie zdrowia młodzieży powinno więc odnosić się do tego ważnego kontekstu ich życia, jakim jest kontekst rówieśniczy oraz kształtowania umiejętności społecznych ważnych dla budowania i utrzymywania satysfakcjonujących relacji.

\section{BIBLIOGRAFIA}

Bardziejewska M., Okres dorastania. Jak rozpoznać potencjał nastolatków? [w:] Psychologiczne portrety człowieka. Praktyczna psychologia rozwojowa, red. A.I. Brzezińska, Gdańskie Wydawnictwo Psychologiczne, Gdańsk 2015.

Beisert M., Dorastanie seksualne - pomost ku dorostości, [w:] Psychologia rozwiąywania problemów szkoły, red. J. Miluska, „Bonami” Wydawnictwo - Drukarnia, Poznań 2001.

Beisert M., Trud dorastania seksualnego, [w:] Seksualność w cyklu życia człowieka, red. M. Beisert, Zakład Wydawniczy - K. Domke, Poznań 2004.

Bierman K., Wargo J.B., Predicting the longitudinal course associated with aggressive rejected, aggressive (non rejected), and rejected (non aggressive) status, Development and Psychopathology, 1995, 7(4).

Bobrowski K., Czas wolny a zachowania ryzykowne młodzieży, Alkoholizm i Narkomania, 2007, 20, 3.

Choukas-Bradley S., Prinstein M.J., Peer Relationships and the Development of Psychopathology, [w:] Handbook of Developmental Psychopathology, red. M. Lewis, K.D. Rudolph, Springer Science+Business Media, New York 2014.

Cillessen A.H., Van Ijzendoorn H.W., Van Lieshout C.F., Hartup W.W., Heterogeneity among peer-rejected boys: Subtypes and stabilities, Child Development, 1992, 63(4).

\footnotetext{
${ }^{65}$ S.S. Luthar, Resilience in development, s. 754.

${ }^{66}$ Gauze, Bukowski, Aquan-Assee, Sippola, 1996, za: C.L. Reitz-Krueger i in., Community Influence, s. 74.

${ }^{67}$ C.L. Reitz-Krueger i in., Community Influence, s. 74.
} 
Connolly J., Johnson A., Adolescents' romantic relationships and the structure and quality of their close interpersonal ties, Personal Relationships, 1996, 3.

Crick N.R., Dodge K.A., A review and reformulation of social information processing mechanisms in children's social adjustment, Psychological Bulletin, 1994, 115.

Cybal-Michalska A., Kanclerz B., Myszka-Strychalska L., Peret-Drążewska P., Młodzież w sferze doświadczeń edukacyjno-zawodowych, Wydawnictwo Naukowe UAM, Poznań 2018.

Dodge K.A., Coie J.D., Social-information processing factors in reactive and proactive aggression in children's peer groups, Journal of Personality and Social Psychology, 1987, 53(6).

Dunphy D., The social structure of urban adolescent peer groups, Sociometry, 1963, 26.

Flannery D.L., Hussey D., Jefferis E. Adolescent Delinquency and Violent Behavior, [w:] Handbook of adolescent behavioral problems: evidence-based approaches to prevention and treatment, red. T.P. Gullotta, G.R. Adams, Springer, New York 2005.

Fleming C.B., Catalano R.F., Haggerty K.P., Abbott R.D., Relationships between level and change in family, school, and peer factors during two periods of adolescence and problem behavior at age 19, Journal of Youth and Adolescence, 2010, 39(6).

Foster S.L., Aggression and Antisocial Behavior in Girls, [w:] Handbook of Behavioral and Emotional Problems in Girls, red. D.J. Bell, S.L. Foster, E.J. Mash, Cambridge University Press, New York 2005.

Furman W., Shaffer L., The role of romantic relationships in adolescent development, [w:] Adolescent romantic relations and sexual behavior: Theory, research and practical implications, red. P. Florsheim, Lawrence Erlbaum Associates, Mahwah, NJ 2003.

Goodman N., Wstęp do socjologii, Zysk i S-ka Wydawnictwo, Poznań 1997.

Izdebski Z., Wiedza, przekonania o HIV/AIDS w społeczeństwie polskim. Zachowania seksualne, Wydawnictwo Naukowe PWN, Warszawa 2000.

Jankowiak B., Gulczyńska A., Wczesna inicjacja seksualna młodzieży - przyczyny i konsekwencje, Kultura - Społeczeństwo - Edukacja, 2014, 5(1).

Jaskulska S., Poleszak W., Wykluczenie rówieśnicze, [w:] Wychowawcze i społeczno-kulturowe kompetencje wspótczesnych nauczycieli. Wybrane konteksty, red. J. Pyżalski, theQ studio, Łódź 2015.

Jessor R., Risk Behavior in Adolescence: A Psychosocial Framework for Understanding and Action, Journal of Adolescent Health, 1991, 12.

Jessor R., Van Den Bos J., Vanderryn J., Costa F.M., Turbin M.S., Protective factors in adolescent problem behavior: Moderator effects and developmental change, Developmental Psychology, 1995, 31.

Kernberg O.F., Związi miłosne, Zysk i S-ka Wydawnictwo, Poznań 1998.

Kossowska A., Mościkier A., Grupa rówieśników a przestępczość młodzieży, [w:] Zagadnienia nieprzystosowania społecznego i przestępczości w Polsce, Ossolineum, Wrocław - Warszawa - Kraków - Gdańsk 1978.

Krukowski A., Problemy zapobiegania przestępczości, Państwowe Wydawnictwo Naukowe, Warszawa 1982.

Liberska H., Głogowska K., Deja M., Przywiązanie do rodziców i rówieśników jako predyktor samooceny w okresie adolescencji, Czasopismo Psychologiczne, 2016, 22, 2.

Liem G.A., Martin A.J., Peer relationships and adolescents' academic and non-academic outcomes: same-sex and opposite-sex peer effects and the mediating role of school engagement, The British Psychological Society, 2011.

Luthar S.S., Resilience in development: A synthesis of research across five decades, [w:] Developmental Psychopathology: Risk, disorder, and adaptation, red. D. Cicchetti, D.J. Cohen, Wiley, New York 2006. 
Misztal B., Grupy rówieśnicze młodzieży, Ossolineum, Warszawa 1974.

Mościcka L., Przestępczość nieletnich, Ossolineum, Wrocław 1970.

Newman B.M., Newman P.R., Development through life: a psychosocial approach, Brooks/Cole Publishing Company, California 1987.

Obuchowska I., Adolescencja, [w:] Psychologia rozwoju człowieka. Charakterystyka okresów życia człowieka, t. 2, red. B. Harwas-Napierała, J. Trempała, Wydawnictwo Naukowe PWN, Warszawa 2005.

Orejudo S., Puyuelo M., Fernandez-Turrado T., Ramos T., Optimism in adolescence: A crosssectional study of the influence of family and peer group variables on junior high school students, Personality and Individual Differences, 2012, 52.

Pawełczyńska A., Przestępczość grup nieletnich, Książka i Wiedza, Warszawa 1964.

Piotrowski K., Wojciechowska J., Ziółkowska B., Rozwój nastolatka. Późna faza dorastania, [w:] Niezbędnik dobrego nauczyciela, red. A.I. Brzezińska, Instytut Badań Edukacyjnych, Warszawa 2014.

Prinstein M.J., La Greca A.M., Childhood peer rejection and aggression as predictors of adolescent girls' externalizing and health risk behaviors: A 6-year longitudinal study, Journal of Consulting and Clinical Psychology, 2004, 72(1).

Reitz-Krueger C.L., Nagel A.G., Guarnera L.A., Reppucci N.D., Community Influence on Adolescent Development, [w:] Handbook of Adolescent Behavioral Problems: Evidence-Based. Approaches to Prevention and Treatment, red. T.P. Gullotta i in., Springer Science+Business Media, New York 2015.

Rew L., Carver T., Li Ch., Early and risky sexual behavior in a sample of rural adolescents, Issues in Comprehensive Pediatric Nursing, 2011, 34.

Romano J.L., Prevention Psychology: Enhancing Personal and Social Well-Being, American Psychological Association 2015.

Salvy S., de la Haye K., Bowker J.C., Hermans R.C.J., Influence of peers and friends on children's and adolescents' eating and activity behaviors, Physiology and Behavior, 2012, 106(3).

Sieving R.E., Eisenberg M.E., Pettingell S., Skay C., Friends' influence on adolescents' first sexual intercourse, Perspectives on Sexual and Reproductive Health, 200, 38.

Skorny Z., Proces socjalizacji dzieci i młodzieży, Wydawnictwa Szkolne i Pedagogiczne, Warszawa 1987.

Tucker Halpern C., Biological Influences on Adolescent Romantic and Sexual Behavior, [w:] Adolescent romantic relations and sexual behavior: Theory, research and practical implications, red. P. Florsheim, Lawrence Erlbaum Associates, Mahwah, NJ 2003.

Weinstein S.M., Mermelstein R.J., Hedeker D., Hankin B.L., Flay B.R., The Time-Varying Influences of Peer and Family Support on Adolescent Daily Positive and Negative Affect, Journal of Clinical Child and Adolescent Psychology, 2006, 35, 3.

Winters K.C., Botzet A.M., Fahnhorst T., Stinchfield R., Koskey R., Adolescent Substance Abuse Treatment: A Review of Evidence-Based Research, [w:] Adolescent Substance Abuse Evidence-Based Approaches to Prevention and Treatment, red. C.G. Leukefeld, T.P. Gullotta, M. Staton-Tindall, Springer Science+Business Media, New York 2009. 